\title{
Chromosomal analysis of embryos produced by artificially inseminated superovulated cattle
}

\author{
WA King ${ }^{1,2}$, A Verini Supplizi ${ }^{2,3}$, HEP Diop ${ }^{2,4}$, D Bousquet ${ }^{5}$ \\ 1 University of Guelph, Department of Biomedical Sciences, \\ Ontario Veterinary College, Guelph, ON, N1G 2W1, Canada; \\ ${ }^{2}$ Université de Montréal, centre de recherche en reproduction animale, faculté \\ de médecine vétérinaire, CP5000, Saint-Hyacinthe, PQ, J2S 7C6 Canada; \\ ${ }^{3}$ Instituto di Produzioni Animali, Facoltà de Medicina Veterinaria, \\ Via San Costanzo 4, 06100 Perugia, Italy; \\ ${ }^{4}$ École inter-États des sciences et médecine vétérinaire, département Chirurgie \\ et Reproduction, BP 5077 Dakar, Senegal; \\ ${ }^{5}$ BOVITEQ, 1425, Grand Rang Saint-François, Saint-Hyacinthe, PQ, J2S 7A9 Canada;
}

(Received 23 June 1994; accepted 14 November 1995)

Summary - To determine the chromosomal complement of pre-morula bovine embryos, 30 Holstein heifers were superovulated and inseminated and their embryos were subjected to chromosome analysis on days 2,3 or 4 . Of the 298 embryos/ova recovered, 101 had one or more cells in metaphase and of these, 60 could be karyotyped. Eight of the karyotyped embryos were chromosomally abnormal, including 3 triploids, 1 tetraploid and 4 mixoploids. It was concluded that the abnormalities occurred at or shortly after the time of fertilization.

bovine / embryo chromosome / triploid / tetraploid / mixoploid

Résumé - Analyse chromosomique chez des embryons provenant de vaches superovulées et inséminées artificiellement. Afin de déterminer la garniture chromosomique d'embryons bovins aux stades de pré-morula, 30 génisses. Holstein ont été superovulées et inséminées. Les embryons furent récoltés aux jours 2,3 ou 4 et soumis à une analyse chromosomique. Sur un total de 298 embryons/ovules récoltés, 101 montraient une ou plusieurs cellules en métaphase et 60 de ceux-ci ont pu être examinés pour leur caryotype. Huit embryons analysés présentaient une garniture chromosomique anormale : 3 triploïdes, 1 tétraploïde et 4 mixoplö̈des. Il est conclu que les anomalies se produisent au moment de la fertilisation ou juste après.

bovin / chromosome d'embryon / triploïde / tétraploïde / mixoplö̈de 


\section{INTRODUCTION}

Under intense agricultural management superovulation is used to induce multiple ovulation in cattle to provide genetically valuable embryos for collection and transfer. However, only about $60 \%$ of the embryos that are collected from superovulated cattle have normal morphology and are considered suitable for transfer (Schneider Jr, et al, 1980; Schiewe et al, 1987; Lopez Gatius et al, 1988). In humans, chromosomal abnormalities in the embryo or fetus are the most frequent causes of malformations and pregnancy failure (Jacobs et al, 1978). Chromosomal analysis of cattle embryos at the morula and blastocyst stages, when embryo transfer is usually performed, has revealed abnormalities that are thought to compromise development (King, 1991). These abnormalities include aneuploidy, mixoploidy and polyploidy (for review see King, 1990). Prior to the morula and blastocyst stages very few observations on the chromosomal constitution of embryos produced by superovulated cattle have been documented (King and Picard, 1985; Murray et al, 1985). Hence, little is known of the situation close to the time of fertilization.

The objective of this study was to determine the chromosomal complement of pre-morula stage embryos produced by superovulated cattle. Some of the embryos reported here were included in a preliminary report published in abstract form (Verini Supplizi et al, 1988).

\section{MATERIALS AND METHODS}

Embryos were produced by superovulated Holstein heifers inseminated once or twice with semen from a highly fertile Holstein bull during the $24 \mathrm{~h}$ following onset of behavioural estrus. Superovulation was induced by treatment with folliclestimulating hormone (FSH-p; Burns-Biotech Laboratory, Oakland, CA, USA) and cloprostenol (Estrumate: ICI Pharms, Mississauga, ON, Canada) as previously described (King et al, 1987). Females were checked for signs of behavioural estrus twice daily. The first detection of behavioural estrus was designated day zero.

Embryos were collected by post-mortem retrograde flush of the oviducts on day 2 $(n=6), 3(n=23)$ and $4(n=1)$. Only one oviduct from 11 of the heifers was available for use in this study. For all collections the flushing medium was Dulbecco's phosphate-buffered saline (PBS, $\mathrm{pH} 7.2$ ) supplemented with $2 \%$ fetal calf serum (FCS) and antibiotics (100 iu penicillin, $100 \mu \mathrm{g}$ streptomycin/ml). Once the embryos were located in the flushing medium they were washed in PBS containing $10 \%$ FCS and antibiotics and transferred to Hams F10 containing 20\% FCS and antibiotics and colcemide $(0.05 \mu \mathrm{g} / \mathrm{ml}$ medium; Sigma, Saint Louis, MO, USA). The embryos were incubated in this medium for $4-8 \mathrm{~h}$ and then fixed individually on slides as previously described (King et al, 1979). Slides were then stained with Giemsa and examined for cell number and chromosome composition. Fertilization was evaluated after fixation and was considered to have occurred if any of the following were observed: mitotic chromosomes; 2 or more pronuclei/nuclei; or 2 or more blastomeres. Ova that presented meiotic chromosomes or lacked nuclei were considered unfertilized. 


\section{RESULTS}

Flushing the reproductive tracts of the 30 females yielded a total of 298 embryos/ova. The mean rate of fertilization (percent of total recovery) was $83.2 \%$. In all 101 embryos (33.9\%) had one or more cells in metaphase. The karyotype of 60 of these embryos (59.4\%) could be determined while 41 had metaphase spreads that were either incomplete or of insufficient quality for analysis. Of the 60 karyotyped embryos, $52(86.6 \%)$ were found to be diploid (60XX or $60 \mathrm{XY})$ and $8(13.3 \%)$ were other than diploid (table I). The abnormal complements included 3 triploids, 1 tetraploid and 4 mixoploids. The triploid and tetraploid embryos were at the 2-cell stage and each embryo presented 2 metaphase spreads. Three of the 4 mixoploid embryos had cleaved to 2-cell stage although 4 nuclei ( 2 haploid and 2 diploid) were present in each. The fourth mixoploid had not cleaved but contained a haploid and a diploid nucleus (fig 1). The diploid nucleus in this embryo contained 62 chromosomes. In all cases the abnormal embryos were among the least developmentally advanced embryos, estimated on the basis of cell number, within the flush of the donor female from which they originated (table I).

Table I. Stage and withinflush range of development of bovine embryos with abnormal chromosomal complement.

\begin{tabular}{lccc}
\hline Abnormality & Karyotype & \multicolumn{2}{c}{ Number of cells } \\
& & Embryo & Range in collection \\
\hline Triploidy & $90 \mathrm{XXX}$ & 2 & $1-4$ \\
& $90 \mathrm{XX} ?^{*}$ & 2 & $1-4$ \\
& $90 \mathrm{X} ?^{*}$ & 2 & $1-4$ \\
Tetraploidy & $120 \mathrm{XXXX}$ & 2 & $1-4$ \\
Mixoploidy & $30 \mathrm{X} / 60 \mathrm{XY}$ & 2 & $1-4$ \\
& $30 \mathrm{Y} / 60 \mathrm{XY}$ & 2 & $1-4$ \\
& $30 \mathrm{Y} / 60 \mathrm{XX}$ & 2 & $1-4$ \\
& $30 \mathrm{X} / 62 \mathrm{XX}$ & 1 & $1-8$ \\
\hline
\end{tabular}

* Sex chromosome could not be identified.

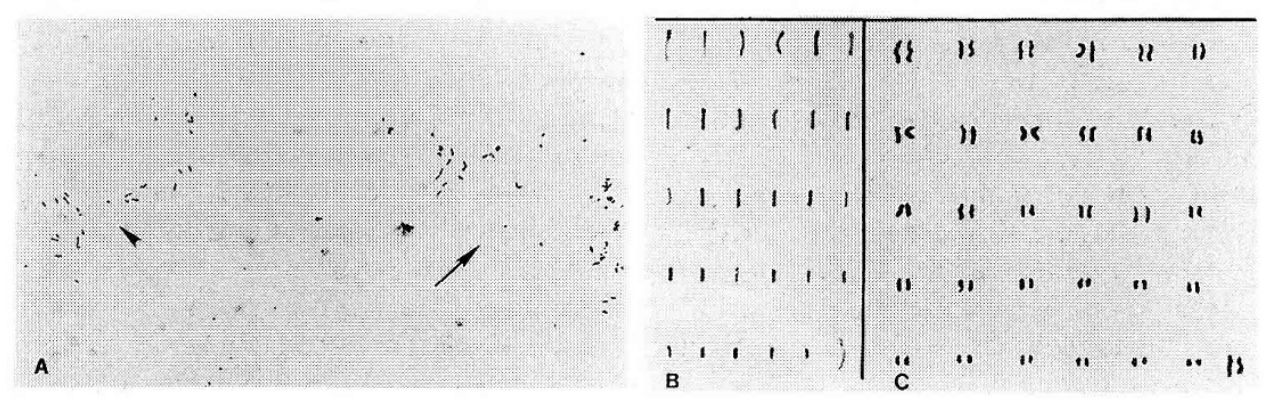

Fig 1. Chromosome preparation from a one cell mixoploid bovine embryo. A: Two separate metaphase spreads of which one is haploid (arrowhead) and one is diploid (arrow). B: Karyotype of the haploid (30X) metaphase. C: Karyotype of the diploid (62XX) metaphase. 


\section{DISCUSSION}

Chromosome abnormalities have been observed in the embryos of most domestic animals. In sheep and pigs, a frequency of chromosomally abnormal embryos of 10.4 and $6.6 \%$, respectively, has been reported (for review see King, 1990). In cattle the frequency varies from 0 to $36.3 \%$ (table II) according to the stage of development and morphological features of the embryo. In the present study of days 2-4 embryos, ranging from 1-8 cells, a frequency of $13.3 \%$ was noted while Hare et al (1980), reported a frequency $1.9 \%$ in elongated blastocysts on days $12-18$. The low frequency at the end of the second week of development in the elongated blastocyst stage suggests a loss of abnormal embryos as development progresses. BenevedesFilho et al (1992) reported a frequency of $35.8 \%$ in day 7 embryos which exhibited reduced cell number, abnormal morphology and low developmental potential. Similarly, King et al (1987) found a higher rate of chromosomally abnormal embryos on day 7 among morphologically abnormal embryos with low cell numbers than among morphologically normal ones. In the present study the abnormal embryos were among the least developmentally advanced within individual donors (table I). If indeed chromosomally abnormal embryos have a slower rate of development and hence a lower cell number, the present observations suggest that development may begin to slow down as early as day 2 .

Table II. Summary of cytogenetics studies of in vivo-produced bovine embryos.

\begin{tabular}{|c|c|c|c|c|}
\hline \multirow{2}{*}{ Stage of development } & \multicolumn{3}{|c|}{ Number of embryos } & \multirow{2}{*}{ Reference } \\
\hline & Total & Analyzed & Abnormal (\%) & \\
\hline Zygote to blastocyst & 134 & 34 & $(11.8)$ & Murray et $a l, 1985$ \\
\hline Zygote to blastocyst & 548 & 265 & $(7.1)$ & Gayerie de Abreu et al, 1984 \\
\hline Morula & 24 & 11 & $4 \quad(36.3)$ & King and Picard, 1985 \\
\hline Morula/blastocyst & 163 & 39 & $14 *(35.8)$ & Benevides-Filho et al, 1992 \\
\hline Morula/blastocyst & 126 & 119 & $16^{* *}(13.4)$ & King et al, 1987 \\
\hline $\begin{array}{l}\text { Elongated blastocyst } \\
\quad \text { (days } 12-18 \text { ) }\end{array}$ & 198 & 159 & $3(1.9)$ & Hare et al, 1980 \\
\hline $\begin{array}{l}\text { Elongated blastocyst } \\
\quad \text { (days } 12-16 \text { ) }\end{array}$ & 12 & 12 & 0 & McFeely and Rajakoski, 1968 \\
\hline Total & 1350 & 683 & $71 \quad(10.4)$ & \\
\hline
\end{tabular}

* Eleven of the 14 were morphologically abnormal embryos with low cell number; ${ }^{* *}$ all 16 were morphologically abnormal embryos with low cell number.

Chromosome analysis of in vitro-produced bovine embryos has shown abnormalities in $12.1 \%$ of embryos at the 2-cell stage, $20.0-36.4 \%$ at 4 - to 16-cell stage and $44.2 \%$ at blastocyst (Iwasaki et al, 1989). Kawarsky (1994) has noted a frequency of abnormalities of $27.4 \%$ on day 2 (1-8 cells) and $32.1 \%$ on day 5 (8-cell stage to morula) in vitro. As with the in vivo studies, both of these in vitro studies suggest an accumulation of chromosomally abnormal embryos over the first week of development. Unfortunately the limitation of in vitro culture prevents monitoring development beyond the blastocyst stage into the second week of development to 
determine if there is an elimination of abnormal embryos as the embryo begins to elongate.

All 8 abnormal embryos were either 1 or 2 cells suggesting that the abnormality occurred at or close to the time of fertilization before completion of the first cell cycle. The 3 triploids and 1 tetraploid were 2-cell embryos. Unfortunately, the exact origin of the extra haploid set(s) of chromosomes could not be determined. In humans, triploid fetuses originate from dispermic fertilization (66\%), diploid sperm $(24 \%)$ or diploid oocytes (10\%; Jacobs et al, 1978). Tetraploid embryos are less common and mechanisms leading to their production are not well studied. They could, however, arise by combinations of the mechanisms proposed for triploids as well as by failure of cytokinesis at first cleavage or by endoreduplication of the pronuclei. In cattle all of these pathways are possible since polyspermic fertilization, diploid sperm, diploid oocytes and endoreduplication have been reported (King et al, 1988; Iwasaki et al, 1989; Yadav et al, 1991; Kawarsky, 1994). In pigs it has been reported that the incidence of polyploidy arises due to ageing of the oocyte when insemination is delayed (Bomsel-Helmreich, 1961). However, this has not been confirmed in cattle.

All 4 of the mixoploid embryos exhibited haploid nuclei (2 in the 3 two-cell embryos and 1 in the 1-cell embryo). The presence of a $\mathrm{Y}$ chromosome in the haploid cells in 2 of the embryos suggests that the oocytes leading to these embryos were fertilized by 2 spermatozoa. The X-chromosome bearing haploid cells may have originated from a spermatozoon, a binucleated oocyte or a polar body. The fate of the haploid cells is not known. King and Picard (1985) and Iwasaki and Hamano (1991) described morula and pre-morula with haploid cells. However, older embryos with such cells have not been reported. It is possible that these nuclei die, become quiescent or are somehow eliminated from the embryo. It is also possible that they eventually fuse with their diploid cohorts as diploid-triploid mixoploids have been reported in blastocysts and elongated blastocysts (Hare et al, 1980; King et al, 1987).

One aneuploid metaphase was observed in the 1-cell mixoploid (30X/62XX) embryo. This low incidence of aneuploidy $(1 / 60 ; 1.7 \%)$ is consistent with the low incidence of aneuploid spermatozoa (2.8\%: Longue and Harvey, 1978) and ova (5.8\%: Yadav et al, 1991).

It was concluded that roughly $13 \%$ of day $2-4$ embryos from superovulated cattle that could be cytogenetically analyzed were chromosomally abnormal. The abnormalities most likely arose at or soon after fertilization due to fertilization by a second spermatozoon or failure of polar body extrusion.

\section{ACKNOWLEDGMENTS}

The financial support of Natural Sciences and Engineering Research Council of Canada and the Canadian Association of Animal Breeders is appreciated. Scholarships from the government of Italy (AVS) and the Canadian International Development Agency (HEPD) are gratefully acknowledged. 


\section{REFERENCES}

Benevides-Filho IM, Pinheiro LEL, Rodriguez CFM, Carvalho C (1992) Cytogenetic analysis of degenerated embryos and non-fertilized structures obtained from superovulated cows. Proc 10th Eur Colloq Cytogenet Domest Anim, Utrecht, The Netherlands, 126-130

Bomsel-Helmreich O (1961) Hétéroploidie expérimentale chez la truie. Proc IV Int Congr Anim Reprod Insem Artif, The Hague, The Netherlands, 1-4

Gayerie de Abreu F, Lamming GE, Shaw RC (1984) A cytogenetic study of early stage bovine embryos-relation with embryo mortality. Proc X Int Congr Anim Reprod Insem Artif, Urbana, IL, USA, 82-84

Hare WCD, Singh EL, Betteridge KJ et al (1980) Chromosomal analysis of 159 bovine embryos collected 12 to 18 days after estrus. Can J Genet Cytol 22, 615-626

Iwasaki S, Hamano S (1991) Occurrence of haploid cells bearing Y chromosomes in bovine embryos fertilized in vitro. $J$ Hered $82,420-421$

Iwasaki S, Shioya Y, Masuda H, Hanada A, Nakahara (1989) Incidence of chromosomal anomalies in early bovine embryos derived from in vitro fertilization. Gamete Res 22, 83-91

Jacobs PA, Angel RR, Buchanan IM, Hassold TJ, Matsuymama AM, Manuel B (1978) The origin of human triploids. Ann Hum Genet (Lond) 42, 49-52

Kawarsky SJ (1994) Cytogenetics and development of bovine embryos produced by abnormal spermatozoa. MSc Thesis, University of Guelph, Canada

King WA (1990) Chromosome abnormalities and pregnancy failure: In: Advances in Veterinary Science and Comparative Medicine: Domestic Animal Cytogenetics (RA McFeely, ed), Academic Press Inc, New York, USA, Vol 43, 229-250

King WA (1991) Embryo-mediated pregnancy failure in cattle. Can Vet $J 32$, 99-103

King WA, Picard L (1985) Haploidy in preattachment bovine embryos. Can J Genet Cytol $27,69-73$

King WA, Linares T, Gustavsson I, Bane A (1979) A method for preparation of chromosomes from bovine zygotes and blastocysts. Vet Sci Commun 3, 51-56

King WA, Guay P, Picard P (1987) A cytogenetical study of 7-day-old bovine embryos of poor morphological quality. Genome 29, 160-164

King WA, Xu KP, Sirard MA et al (1988) Cytogenetic study of parthenogenetically activated bovine oocytes matured in vivo and in vitro. Gamete Res 20, 265-274

Logue DN, Harvey MJA (1978) Meiosis and spermatogenesis in bulls heterozygous for a presumptive 1/29 Robertsonian translocation. J Reprod Fertil 54, 159-165

Lopez Gatius F, Camón Urgel J, Angulo Asensio E (1988) Effects of single deep insemination on transferable embryo recovery rates in superovulated dairy cows. Theriogenology $30,877-885$

McFeely RA, Rajakoski E (1968) Chromosome studies on early embryos of the cow. Proc VI Int Congr Anim Reprod Artif Insemin, Paris, France, 905-907

Murray JD, Moran C, Boland MP, Doff AM, Nancarrow CD (1985) Cytogenetic analysis of 34 early stage bovine embryos from superovulated Hereford donors. Can J Genet Cytol 27, 483-486

Schiewe MC, Looney CR, Johnson CA, Hill KG, Godke RA (1987) Transferable embryo recovery rates following different insemination schedules in superovulated beef cattle. Theriogenology 28, 395-406

Schneider Jr HF, Castleberry RS, Griffin JL (1980) Commercial aspects of bovine embryo transfer. Theriogenology 13, 73-85

Verini Supplizi A, King WA, Xu KP (1988) The chromosomes of early cleavage stage bovine embryos. Proc 8th Eur Colloq Cytogenet Domest Anim, Bristol, UK, 23

Yadav BR, King WA, Xu KP, Pollard JW, Plante L (1991) Chromosome analysis of bovine oocytes cultured in vitro. Genet Sel Evol 23, 191-196 